Michał Pawelczyk

UNIWERSYTET ŁÓDZKI

\title{
Etnologiczna interpretacja symboliki zła w filmie Wernera Herzoga Nosferatu wampir
}

Tytuł opracowania precyzyjnie określa przedmiot niniejszych rozważań. Jest nim próba interpretacji wybranych wątków symbolicznych w dziele filmowym Wernera Herzoga zatytułowanym Nosferatu wampir. Będzie to działanie oparte na Jungowskiej procedurze amplifikacji, która do badań nad symboliką w kontekście filmu zaproponował amerykański filmoznawca Don Fredericksen. Stanowi ona alternatywę wobec analitycznej koncepcji rozszyfrowywania filmowych znaczeń, która traci swoje zastosowanie $z$ chwila, gdy na scenę wkraczają odniesienia symboliczne ${ }^{1}$.

\section{Kilka słów na temat symbolu}

Na potrzeby niniejszego tekstu przyjmiemy za Gilbertem Durandem, iż symbol jest to znak, który „odsyła do niewysłowionego i niewidzialnego oznaczonego" ${ }^{2}$. Innymi słowy - znacząca, a więc widzialna strona symbolu (signifiant) odsyła do abstrakcji lub sfery rzeczywistości (signifié), która ze swej natury jest niepoznawalna. Symbol reprezentuje tę rzeczywistość w ludzkim świecie, jest jedynym dowodem (ewentualnie: argumentem) na istnienie rzeczywistości, do której odsyła. Podobny pogląd na zjawisko symbolu głosił twórca psychologii głębi, Carl Gustav Jung, zdaniem którego symbol jest „najlepszym możliwym kształtem jakiejś rzeczy stosunkowo nieznanej, której zatem nie umielibyśmy od razu wskazać w sposób jaśniejszy i bardziej charakterystyczny"3.

1 Zob. D. Czaja, Symbol i film. Uwagi metodologiczne, „Polska Sztuka Ludowa. Konteksty" 1992, nr 3-4, s. 40.

2 G. Durand, Wyobraźnia symboliczna, Warszawa 1986, s. 29.

3 C. G. Jung, Typy psychologiczne, Warszawa 2009, s. 524. 
Przyjmiemy zatem, że symbol jest szczególnym rodzajem znaku, który wykracza poza semiotyczny, strukturalistyczny układ „znaczace - znaczone”. W przypadku symbolu sytuacja nie jest tak prosta, jak w przypadku zwykłego znaku, ponieważ symbol jest $z$ natury polisemiczny, łaczy $w$ sobie rozmaite znaczenia, ponadto ma charakter redundantny ${ }^{4}$. Widzialna połowa symbolu, owo „znaczące”, nie odsyła wprost do jakiegoś konkretnego, znanego przedmiotu, lecz reprezentuje rzeczywistość nadzmysłowa, niedostępna ludzkiej percepcji, odsyła do transcendencji, kumulując w sobie wiele znaczeń i sensów.

Po krótkim szkicu teoretycznym przejdźmy do metody - wcale nie nowatorskiej, gdyż jej geneza sięga początków XX w. Mowa tutaj o metodzie amplifikacji autorstwa C. G. Junga. Najogólniej rzecz ujmując, procedura amplifikacji polega na rozwinięciu symboliki, przedstawionej w określonej kulturowej narracji (w tym przypadku jest to dzieło filmowe), w pewien konkretny sposób, a mianowicie na ukazaniu jej w kontekście innych symboli, tworzacych dla niej swoisty plan odniesienia. Dariusz Czaja streszcza za Fredericksenem myśl C. G. Junga w następujących słowach:

Amplifikować to $\mathrm{w}$ istocie współmyśleć $z$ symbolem. [...] Amplifikacja nie rozwiazuje zawiłości symbolu, nie rozkłada go analitycznie. Dostarcza jedynie paralelnych wobec interpretowanego symbolu ekspresji zaczerpniętych $\mathrm{z}$ religii, mitologii, folkloru, takich jednak, które maja podobny temat, znaczenie i funkcję .

Zabieg ten, polegający na usytuowaniu symbolu w kontekście innych, posiadajacych podobne konotacje semantyczne, pozwala ukazać jego miejsce w danym ciągu symbolicznym, tym samym rozjaśniając jego sens bez konieczności dokonywania analitycznej dekompozycji. Procedura amplifikacji jawi się zatem jako zabieg stricte hermeneutyczny, nakazuje bowiem interpretować dany fenomen (w tym przypadku symbol) na tle innych jemu pokrewnych; każe „odczytywać" znaczenia symbolu zawsze w odniesieniu do kontekstu kulturowego i historycznego, w którym jest rozpatrywany. W ten właśnie sposób poznający podmiot „współmyśli” $z$ symbolem, aktywnie re-konstruuje oraz poszerza jego sensy i znaczenia - koło hermeneutyczne zatacza kolejny, szerszy krag na drodze do rozumienia.

Film Nosferatu wampir (Nosferatu. Phantom der Nacht) stanowi remake filmu Friedricha Wilhelma Murnaua $z$ roku 1922. Podobnie

\footnotetext{
${ }^{4}$ G. Durand, dz. cyt., s. 26.

5 D. Czaja, dz. cyt., s. 41.
} 
jak pierwowzór, powstał on na podstawie powieści Brama Stokera zatytułowanej Dracula (1897). Film W. Herzoga jest jednak czymśs więcej niż tylko ponownym sfilmowaniem pierwszej wielkiej opowieści o hrabi $z$ Transylwanii. Reżyser (będacy jednocześnie autorem scenariusza i producentem) proponuje nam za pośrednictwem swojego dzieła wyprawę szczególną. Jest to wędrówka przez krainę symboli i mitów, równie starych jak ludzkość, ale wciąż aktualnych przez zawarte $\mathrm{w}$ nich pytania dotyczace natury ludzkiej, problemu dobra i zła oraz związku, jaki łączy człowieka $z$ otaczającym go światem przyrody. Wszystkie odniesienia symboliczne zawarte w filmie W. Herzoga są w mniejszym lub większym stopniu powiązane $z$ głównym bohaterem ekranizacji - tytułowym wampirem, Nosferatu. To wokół niego koncentruje się tok filmowej narracji, a co za tym idzie, wszelka symbolika.

Próbując zastosować w praktyce procedurę amplifikacji, pozwolę sobie wyznaczyć w tym miejscu główną kategorię symboliczną, wokół której skupiona będzie moja uwaga podczas interpretacji dzieła filmowego, a także kategorie względem niej wtórne (poboczne), lecz niezbędne, pozwalające bowiem dookreślić znaczenie kategorii głównej, której sens może zostać zrozumiany tylko poprzez szereg odniesień o charakterze symbolicznym. Wybranym przeze mnie pojęciem głównym jest zło. Zło, będące jedną $z$ dwóch wielkich sił organizujących wszechświat, jest samo w sobie nieuchwytne i wręcz niedefiniowalne. Może jednak zostać określone za pomoca symbolu, jak bowiem wskazywaliśmy na wstępie, powołując się na słowa C. G. Junga i G. Duranda, symbol - ów znaczący obraz - odsyla do tego, co niepojęte, niedostępne ludzkiemu poznaniu.

W zależności od kontekstu kulturowego zło przybiera rozmaite „widzialne" formy, które sa $z$ nim identyfikowane. Relacja ta nie opiera się jednak zawsze na prostym, „dwuskrzydłowym” zwiazku o charakterze semiotycznym (relacji „znaczące - znaczone”). $\mathrm{W}$ pewnych okolicznościach mamy do czynienia $z$ sytuacja o charakterze symbolicznym, bowiem rzecz oznaczona przez symbol jest nieznana, niedostępna, a nawet można rzec - nie do końca określona i może być zrozumiana jedynie za pomoca odniesień i wątków symbolicznych, jakie wypracowała dana kultura ${ }^{6}$. Poniżej przedstawiam swoja propozycję usystematyzowania symboliki $\mathrm{w}$ dziele filmowym W. Herzoga. Przedstawia się ona następująco:

$$
\begin{gathered}
\text { zło (wampir) - śmierć - noc - księżyc - kobieta - krew - zwierzęta } \\
\text { nocne (lunarne) }
\end{gathered}
$$

${ }^{6}$ P. Ricoeur, Symbolika zła, Warszawa 2002, s. 10. 
Ciag symboliczny rozpoczyna się od zła (które w tym przypadku reprezentuje postać wampira) jako kategorii podstawowej i implikującej kolejne sześć kategorii pobocznych. Implikacja zła, a także jego korelatem w wielu kulturach jest śmierć (oraz ściśle związana $z$ nią zaraza, którego to faktu nie przeoczył w swoim dziele również W. Herzog). Z kolei noc, jak możemy przeczytać w Kulturze magicznej Piotra Kowalskiego, stanowi kulturowa metonimię krainy śmierci ${ }^{7}$. $Z$ nocą zaś nierozerwalnie związany jest księżyc, a $z$ nim $z$ kolei kobieta, $z$ uwagi na periodyczne zjawisko menstruacji, sytuujące ją w obrębie natury. Kolejną kategorią proponowanego łańcucha symboli jest krew, wiążąca się zarówno $z$ kobieta, jak i $z$ wampirem (złem), a także zwierzętami nocnymi, których postać wampir często przybiera ${ }^{8}$.

Proponowana konstrukcja, zgodnie $z$ moim wyobrażeniem, winna jawić się czytelnikowi jako spirala wychodzaca $z$ jednego punktu (zło - wampir), która za każdym razem, gdy zatacza nowy krag, poszerza i rozświetla znaczenie poprzednich, poprzez ukazanie łączących je relacji i odniesień symbolicznych. Oczywiście jestem świadomy faktu, iż wybrane przeze mnie dzieło filmowe ma o wiele więcej odniesień symbolicznych niż wskazałem powyżej. Jednak w moim przekonaniu udało mi się dostrzec te najważniejsze, które organizują i współtworza ze sobą w prezentowanym obrazie pewien "dyskurs symboliczny"; pozostaja ze sobą w żywym dialogu.

Należy zaznaczyć, że narracja niniejszego opracowania nie jest równoległa do fabuły filmu. Poszczególne pojęcia, które składają się na zaproponowany przeze mnie ciag symboliczny, będą wyznaczać strukturę tekstu. Zaczniemy zatem od tytułowej postaci wampira, personifikacji zła, choć - jak zobaczymy - o ambiwalentnej naturze.

\section{Wampir}

Początek filmu - bardzo trudno było mi zinterpretować tę scenę ze względu na jej oniryczny charakter, który nie pozwala jednoznacznie stwierdzić, z czym właściwie mamy do czynienia. W moim przekonaniu scena ta ukazuje krainę śmierci, chtoniczny świat, w którym przebywają dusze zmarłych. Prezentowane postacie mężczyzn, kobiet i dzieci jasno daja do zrozumienia, że przed śmiercia nie ma ucieczki i że każdy, prędzej czy później, będzie musiał jej

7 P. Kowalski, Kultura magiczna. Omen, przesad, znaczenie, Warszawa 2007, s. 351.

8 Zob. E. Petoia, Wampiry i wilkołaki. Źródła, historia, legendy od antyku do współczesności, Warszawa 2010, s. 44, 262. 
doświadczyć i pożegnać doczesny świat. Spetryfikowane w tajemniczy, niepokojący sposób istoty, oparte o mury podziemnych lochów, stoja obok siebie w milczeniu, nieruchome, pozbawione życia. Gdy oglądałem tę scenę, za każdym razem stawał mi przed oczami obraz Szeolu i Hadesu, a także sumeryjskiej krainy Arali, gdzie zmarli byli przedstawiani jako cienie, postacie, które nie reprezentowały soba żadnych sił witalnych, a jedynie „bytowały” w podziemnym królestwie śmierci. Do tej sceny można również odnieść passus z książki Jean-Paula Roux, który ostatecznie wyjaśnia rolę owej sceny w filmie, szczególnie w kontekście sceny następnej: „ich [wampirów] ponure królestwo mogłoby równie dobrze zwać się Szeolem lub Hadesem" ". Kolejna scena przedstawia nietoperza w locie. Można zatem wysunąć tezę, iż miejsce, które zostało zaprezentowane $\mathrm{w}$ scenie pierwszej jest właśnie siedliskiem wampira, światem umarłych, domena śmierci, z której przybywa on pod postacia zwierzęcia do ludzkiej ekumeny, zawsze pod osłoną nocy. Zwiazek wampira $z$ nietoperzem i noca wydaje się oczywisty, potwierdzony wieloma przykładami $z$ literatury i kina. Również noc jako czas aktywności nietoperza, a także wampira nie powinna budzić watpliwości. Wszak noc jest korelowana w wielu kulturach (zwłaszcza typu ludowego) ze śmiercią. Mrok jest przeciwstawiany światłu, tak jak śmierć - życiu. „Noc, cisza, pustkowie przywołuja automatycznie całą serię określeń, które stosuje się do przedstawienia obcej krainy śmierci: nierozróżnialność, destrukcję, bezruch i bierność"10. Majac na uwadze te słowa, przypomnijmy sobie obraz prezentowany w pierwszej scenie filmu: szereg zastygłych poza znanym czasem i przestrzenia postaci skapanych w mroku nocy, domenie śmierci, z której przybywa wampir pod postacia nietoperza. Wampir - Nosferatu.

Musimy zauważyć, iż wspaniale skądinąd wykreowana przez Klausa Kinskiego postać Draculi kumuluje w sobie wiele wątków i odniesień symbolicznych, a także dylematów i pytań egzystencjalnych, łączy w sobie dwie, wzajemnie wykluczające się i zwalczające natury.

$Z$ jednej strony wampir pozostaje uosobieniem zła, łaknącym ludzkiej krwi demonem; $z$ drugiej zaś możemy zaobserwować, jak rudymenty człowieczeństwa kołacza się w jego przeklętej duszy, przyprawiając go niekiedy wręcz o rozpacz i melancholię.

Wampir, istota określana przez rozmaite demonologie (w tym polska, „ludowa”) jako inkarnacja czystego zła, bestia żywiąca się

9 J.-P. Roux, Krew. Mity, symbole, rzeczywistość, Kraków 1994, s. 9.

10 E. Petoia, dz. cyt., s. 351. 
krwią niewinnych ofiar, skorelowana ściśle ze śmiercia - jawi się w obrazie W. Herzoga jako postać raczej ambiwalentna. Możemy się zatem zastanawiać, czy mamy tutaj do czynienia $z$ symbolika zła jako takiego, czy może raczej $z$ wątkiem odwiecznej walki dobra ze złem, która rozgrywa się we wnętrzu każdego człowieka? Tytulowy Nosferatu jest bohaterem negatywnym, ale nie jako ten, który świadomie wybrał zło. Wydaje się, że został na owo zło skazany wbrew swej woli, że zła natura nie zdołała do końca przeniknąć jego duszy. Melancholia, smutek, doświadczanie rozpaczliwości własnego położenia i zdolność odczuwania nie pozwalają zakwalifikować Draculi jednoznacznie do strefy mroku. Te cechy nakazuja raczej usytuować wampira w strefie „pomiędzy”, w krainie mediacji; ukazać go jako istotę zawieszona między dwoma wielkimi porządkami, dwiema najważniejszymi kategoriami aksjologicznymi - dobrem i złem. Paradoksalnie, nie możemy jednoznacznie określić statusu aksjologicznego wampira jako jednoznacznie złego właśnie ze względu na to, iż jest on świadomy faktu bycia złym, który to fakt napawa go przygnębieniem i melancholią. Wie doskonale, jaka rola jest mu przypisana w odwiecznym porządku świata i godzi się na taki stan rzeczy. Mimo ambiwalentnych uczuć, jakie wampir wzbudza, w wielu poczynaniach pozostaje on posłuszny demonicznej naturze, a co za tym idzie, czyni zło, którego jednym $z$ korelatów $\mathrm{w}$ kulturze jest śmierć.

\section{Śmierć}

W tym miejscu trzeba jednak wyraźnie oddzielić od siebie dwa aspekty, a właściwie formy czy sposoby umierania. Philippe Aries, autor studium poświęconego śmierci, zaznacza, że nie każda śmierć jest zła. W przeszłości zjawisko śmierci było uważane za należące do naturalnego porządku rzeczy. Była ona oswojona, spodziewano się jej nadejścia ${ }^{11}$. Sprawy przybierały inny obrót, gdy śmierć zaczynała zbierać swe żniwo niespodziewanie i na wielka skalę, a $z$ tym właśnie przypadkiem mamy do czynienia w filmie Nosferatu wampir. Dracula przybywa do Wismaru droga morska, a towarzyszy mu armia szczurów, które w okamgnieniu roznosza po całym mieście zarazę. Śmierć spada na to miejsce niczym grom z jasnego nieba, dziesiątkując mieszkańców; jest to śmierć zła, dzika i nieoswojona, przeciwieństwo ars moriendi - mors repentina ${ }^{12}$. Plaga czarnej śmierci jest efektem pojawienia się zła, które uosabia

11 P. Aries, Człowiek $i$ śmierć, Warszawa 1989, s. 20.

12 Tamże, s. 23. 
wampir. Powiazanie zarazy - dżumy - i wampira jest zabiegiem, którego dokonywano już w XVI w. Zdaniem niektórych ówczesnych kronikarzy, pojawiające się co jakiś czas epidemie czarnej śmierci lub innych chorób były spowodowane działalnościa wampirów, które doprowadzały do wybuchu zarazy (zjadając własny grobowy całun $)^{13}$. Wspomniałem już o szczurach, których powiązanie $z$ zaraza nie jest symboliczne, lecz jak najbardziej dosłowne, jak bowiem powszechnie wiadomo, to one były nosicielami choroby, która poprzez pchły przedostawała się na ludzi. Mimo to szczury wpisuja się $\mathrm{w}$ rekonstruowany $\mathrm{w}$ niniejszym tekście plan symboliczny, albowiem sa znakiem rzeczy obcej i niepoznawalnej dla ludzi żyjacych - reprezentuja śmierć i zło.

Oprócz wątku zarazy, jako synonimu nagłej, niedobrej śmierci, w filmie W. Herzoga możemy dostrzec również odniesienie do formy przedstawienia zjawiska śmierci i marności ludzkiego życia w sztuce. Mowa tu oczywiście o koncepcji vanitas, charakterystycznej zwłaszcza dla malarstwa niderlandzkiego okresu renesansu i baroku ${ }^{14}$. Motyw egzystencjalnego niepokoju związanego $z$ nieuchronnościa śmierci pojawia się w filmie w dwóch konfiguracjach: po raz pierwszy w momencie, gdy ścienny zegar wybija północ podczas kolacji, którą wampir podejmuje Jonathana Harkera. Zegar zwieńczony jest czaszka, a podczas wybijania godziny zamiast kukułki z zegara wysuwa się figurka kościotrupa - personifikacja śmierci - dzierżąca kosę. Moment ten unaocznia marność i kruchość ludzkiego życia, które wyznaczone jest upływem czasu. Wampira jednak upływ czasu nie dotyczy, jest on żywym trupem, dla którego upływ czasu nie ma znaczenia. Po raz drugi możemy odnaleźć odniesienie do idei vanitas, spoglądając na suto zastawiony stół, który po przebudzeniu odnajduje Harker w jednej $z$ komnat zamku. Wśród wielu rodzajów potraw pojawiają się wypchany kogut i bażant, które pełnią tę sama rolę, co czaszka: przypominaja o nieuchronności śmierci.

Oprócz wyżej wymienionych odniesień symbolicznych do sfery śmierci, odnajdujemy w filmie również te dotyczące bezpośrednio postaci samego wampira. Jak doskonale wiemy, wampir, będąc żywym trupem, musi ukrywać się przed światłem dnia. Czyni to zazwyczaj zamykajac się w trumnie lub krypcie, pozostającej jego schronieniem przed promieniami słonecznymi. Mamy tu zatem do czynienia $z$ odniesieniem do sfery chtonicznej, podziemnej. Wampir należy do świata śmierci, a zatem porę dnia spędza pod ziemia, która daje mu schronienie. Jak zauważa Maria Janion, ziemia to naturalne

13 E. Petoia, dz. cyt., s. 262.

14 M. Battistini, Symbole i alegorie, Warszawa 2005, s. 360. 
środowisko wampira. „Ona jest jego schronieniem, otulina i podściółką jego mieszkania - trumny"15. Szukając wyjścia z przeklętego zamku Draculi, Harker natrafia na komorę grobowa, w której odkrywa pograżonego w letargu wampira. Wyruszając w droge do Wiesmaru, wampir podróżuje w trumnie wypełnionej ziemią. $Z$ kolei przybywajac do miasta, Nosferatu lokuje swoja trumnę w opuszczonej cmentarnej kaplicy. Nic w tym dziwnego, wszakże „ulubionymi miejscami, w których pokazywali się zmarli, były cmentarze, zrujnowane zamki i opuszczone opactwa"16. Sfera chtoniczna jest ściśle zwiazana ze zmarłymi, w tym $z$ pozostającymi w stanie pośrednim wampirami. Oprócz odniesień symbolicznych, wskazujacych na powiązanie ziemi ze śmiercią, istnieją jednak także te łączące ją $z$ życiem, regeneracją. Mircea Eliade, opisujac sensy i znaczenia wiązane $z$ ziemią w kulturach ludzkich, zwracał uwagę, iż ziemia rodzi formy żywe, wywodząc je $z$ własnej substancji: „wszystko, co wychodzi z ziemi, obdarzone jest życiem, a wszystko, co powraca do ziemi, na nowo życie uzyskuje"17. Przypadek wampira jedynie pozornie wydaje się tutaj pasować. Nie wraca on do ziemi po to, ażeby zyskać nowe życie. Ziemia stanowi jego schronienie przed światłem dnia, a gdy nadchodzi noc, wypluwa demona $z$ siebie. To nie ziemia regeneruje wampira i zapewnia mu siły witalne, lecz substancja, której poszukuje, błądząc wśród nocy i niepokojąc żywych - krew.

\section{Krew}

Dlaczego wampir potrzebuje karmić się krwią żyjących? Oczywiście dlatego, że sam jej nie posiada, w jego żyłach nie płynie $\dot{z} y-$ ciodajna substancja zapewniająca witalność i energię. W zwiazku $z$ tym, aby móc dalej egzystować, demon musi żywić się krwią ludzi żywych. To, czym jest krew dla wampira, wyraża najlepiej powtarzane co chwila przez obłąkanego sługę Draculi, Reinfielda, zdanie: „Krew to życie!”. Warto zauważyć, że krew ze względu na swoje właściwości jest postrzegana w kulturze w sposób ambiwalentny. Jest życiodajna, ale jednocześnie wiąże się ze śmiercią, szczególnie w przypadku jej przelewania:

Płynąca krew, styczność z nią, przynosi ze sobą skazę śmierci. Wszelka utrata krwi, esencji życia [...] czyni człowieka nieczystym, bo znajdującym się niebezpiecznie blisko stanu zawieszonych taksonomii, braku jednoznacznego przypisania do określonej części wszechświata ${ }^{18}$.

15 M. Janion, Wampir. Biografia symboliczna, Gdańsk 2002, s. 134.

16 Tamże, s. 102.

17 M. Eliade, Traktat o historii religii, Warszawa 2000, s. 272.

18 P. Kowalski, dz. cyt., s. 251. 
W filmie nie ma zbyt wielu scen, w których przelewana jest krew. De facto sa one tylko trzy, ale każda $z$ nich ukazuje inny wymiar zjawiska. Pierwsza scena, która już opisywałem przy okazji omawiania tytułowego bohatera filmu, ukazuje dwuwartościowość krwi, która $z$ jednej strony jest pożądana przez demona, aby zapewnić mu życie, $z$ drugiej zaś - uwalnia szaleństwo i zło (moment, w którym wampir po wyssaniu krwi $z$ palca Harkera rzuca się na niego $z$ obłędem w oczach). Tę niejasność i dwuwartościowość krwi podkreśla Jean-Paul Roux, według którego krew była zawsze uważana za jednocześnie niebezpieczną i uzdrawiająca, nieczysta i czystą ${ }^{19}$. Po raz drugi krew przelana zostaje w momencie, gdy hrabia Dracula odwiedza w nocy Lucy. Kobieta rozmyślnie pozwalając wampirowi wyssać swoją krew, jednocześnie go uwodzi, chce tym samym zyskać na czasie, aby demon nie zdążył wrócić do swej kryjówki przed wschodem słońca. Do trzeciego rozlewu krwi dochodzi w jednej $z$ ostatnich scen filmu, gdy doktor Van Helsing przebija serce Draculi drewnianym kołkiem. Teraz została przelana krew samego wampira, a może ściślej - krew jego ofiar, która sobie przywłaszczył.

W mojej opinii warto również wspomnieć, iż krew jest motywem łączaccym w kulturze postać wampira i kobiety. W jaki sposób? Otóż, obydwie istoty sa w sposób szczególny naznaczone piętnem krwi, jednak na innych poziomach semantycznych. Wampir potrzebuje krwi, aby móc podtrzymywać swoja „połowiczna”" egzystencję; musi pozyskiwać życiodajna substancję, mordując bądź przemieniając żyjacych w podobnych sobie wampirów. Kobieta zaś jest naznaczona piętnem krwi z uwagi na comiesięczne krwawienia menstruacyjne. Krew kobiety miesiaczkującej, jak i ona sama, były i sa związane $z$ rozmaitymi tabu. W obu przypadkach, wampira i kobiety, krew jest związana zarówno $z$ życiem, jak i śmiercią. Wampir potrzebuje jej, by żyć, ale by ja dostać, musi zabić; natomiast krew kobiety $z$ jednej strony warunkuje możliwość powstania nowego życia, $z$ drugiej zaś - utrata krwi kojarzy się ze śmiercią. Mając na uwadze te informacje, można według mnie lepiej zrozumieć relację, jaka łączy w filmie Draculę i Lucy.

\section{Kobieta}

Postać kobiety stanowi ważny wątek w filmie W. Herzoga, bowiem łączy w sobie wiele odniesień symbolicznych i znaczeń kulturowych. To właśnie Lucy, żona Harkera, ma profetyczne sny; przepowiada mężowi, iż jadąc do zamku Draculi, znajdzie się

19 J.-P. Roux, dz. cyt., s. 8. 
$\mathrm{w}$ niebezpieczeństwie. To $\mathrm{z}$ nią wampir wchodzi w kontakt, $z$ początku jedynie w wymiarze onirycznym, później już osobiście proponujac jej rolę swego sojusznika. Gdy Nosferatu „dopada” Harkera w jego komnacie, Lucy zaczyna lunatykować, a obudziwszy się, wykrzykuje imię swojego męża. Wampir, mimo iż oddalony od niej o setki kilometrów, zdaje się słyszeć wołanie kobiety. Wreszcie kobieta przyczynia się do zlikwidowania Draculi, poświęcając jednak własne życie. Widzimy zatem, iż kobieta ukazana jest $z$ jednej strony jako istota niepomiernie silniej uwikłana w rytmy i tryby natury niż mężczyzna, jako istota, do której zło ma dostęp; $z$ drugiej strony zaś - jako jedyna postanawia się temu złu przeciwstawić, aby ocalić życie swojego ukochanego, kładąc na szali własne życie. Co prawda, umiera $z$ winy wampira, ale dzięki jej działaniu Dracula również zostaje zabity, chociaż nie na długo. Ostatecznie, pisze J.-P. Roux, „zwycięża śmierć, a właściwie złe życie, życie grobu. Mamy jeszcze do czynienia $z$ poświęceniem, ale młoda kobieta, która umiera, oddając się wampirowi, umożliwia jego natychmiastowa reinkarnacje" 20 .

Postać kobiety jest w kulturze naznaczona ambiwalencją. Dzięki niej rodzi się nowe życie, ale kojarzy się ją również ze sferą śmierci i zła. Zjawisko menstruacji sytuuje kobiete w bliskich zwiazkach $z$ natura, a więc światem nieoswojonym, dzikim: orbis-exterior. Jak wykazuje M. Eliade, kobieta jest również ściśle kojarzona $z$ ziemią, płodnością i księżycem, a także wężem ${ }^{21}$. Podobne odniesienia występuja w filmie Nosferatu wampir. Tutaj kobieta występuje jako postać, z która zło wchodzi w kontakt, jest też zależna od sił natury (fakt lunatykowania), posiada atrybuty w postaci zwierzat uważanych w kulturze za ambiwalentne (dwa kocięta w pierwszych scenach filmu moga symbolizować $z$ jednej strony niewinność Lucy, z drugiej - wskazywać na jej związek $z$ natura, światem nieoswojonym).

\section{Księżyc}

Słusznie postapi ten, kto zapyta, dlaczego jednym $z$ elementów zaproponowanego łańcucha symbolicznego, który można dostrzec w filmie Nosferatu wampir, stał się księżyc. Przecież nie pojawia się on w kadrze ani na sekundę. Mimo to jego obecność jest wyczuwalna i namacalna, zapewne nie tylko dla antropologa. Księżyc jest ważną figura symboliczną, która, co prawda, nie pojawia się

\footnotetext{
20 Tamże, s. 254.

21 M. Eliade, dz. cyt., s. 207, 259, 260.
} 
bezpośrednio w obrazie filmowym, lecz jego poświata, rozświetlajacca mroki nocy, wystarcza, aby podjacc temat symboliki lunarnej, pozwalającej dookreślić sensy i znaczenia omawianych wcześniej odniesień symbolicznych.

„Księżyc jest pierwszym umarłym” - pisze M. Eliade. I chociaż rozważania rumuńskiego uczonego nie oscylowały w obrębie symboli związanych $z$ postacia wampira, a słowa te wypowiedziane były $\mathrm{w}$ innym kontekście, to $\mathrm{w}$ interesującym nas wymiarze mają również szczególne znaczenie. Skoro księżyc jest pierwszym umarłym, to jego związek ze śmiercia jest oczywisty. Jest ciałem niebieskim rozświetlającym noc, nie ma w sobie jednak witalnej, ożywczej mocy słonecznego światła dnia. Księżyc rzuca zimną, lodowatą poświatę, w niektórych kulturach uważany jest za krainę śmierci ${ }^{22}$. Jest związany $z$ magia, nocą i kobieta, a także ze zwierzętami, które prowadza nocny tryb życia (wilk, nietoperz). Pojawia się na niebie w nocy, kiedy budzą się demony i wampiry wyruszajace ze swych kryjówek w poszukiwaniu pokarmu. Księżyc łączy się również ściśle $z$ kobieta, ponieważ podobnie jak ona, jego sposób bycia opiera się na rytmach, ma charakter cykliczny, jest podporządkowany pewnej periodycznej zmianie ${ }^{23}$. Związek ten widzimy także w filmie, gdy w jednej ze scen Lucy zaczyna lunatykować. Postać kobiety przedstawiona jest tutaj jako zależna od sił natury, którym podporządkowuje się w sposób nieświadomy. Mamy tu też do czynienia ze snem, który można odczytywać jako metonimię śmierci. Widzimy zatem, że srebrny glob wpasowuje się idealnie w ciag symboli skorelowanych ze złem (wampirem), śmiercią, kobieta (a przez nią również $z$ krwia) oraz niektórymi gatunkami zwierzat. Jego rola w filmie nie jest znaczaca jedynie dla widza niezaznajomionego $z$ symbolika lunarna i tematami mitycznymi, do których się ona odnosi. Zostawiając księżyc, przejdźmy do tematyki pokrewnej, a mianowicie zwierząt powiązanych $z$ księżycem oraz ich symbolicznych odniesień.

\section{Zwierzęta lunarne}

Przegląd zwierzat lunarnych występujacych w filmie rozpocznę od stworzenia, którego związek $z$ wampirem jest oczywisty, tj. od nietoperza. Jak wskazuje Piotr Kowalski, „większość cech wiąże nietoperza $z$ demoniczna strefa nocy. Budzi się noca, żeruje niczym wampir wysysający krew swoim ofiarom" ${ }^{24}$.

\footnotetext{
22 Tamże, s. 190.

3 Tamże, s. 186.

24 P. Kowalski, dz. cyt., s. 348.
} 
Ponadto, nietoperz uznawany jest przez wiele kultur za zwierzę nieczyste. Dzieje się tak, ponieważ nie można go zaliczyć do żadnej kategorii taksonomicznej: „fruwa, więc powinien być ptakiem, rodzi się jednak jak ssak żyjący na ziemi. Ma skrzydła, ale nie ma piór. W dodatku jeszcze żeruje noca, kiedy istoty żywe udaja się na spoczynek" 25 . Te cechy, niepozwalające skategoryzować jednoznacznie danej istoty, określaja ja jako graniczna, a zatem ambiwalentna. W polskiej kulturze typu ludowego przeważaja jednak skojarzenia wiążące nietoperza ze złem i śmiercią. Takie jego cechy, jak czarny kolor skrzydeł pozbawionych piór, noc jako czas aktywności, zwyczaj spania głową w dół - składają się na przypisywane temu zwierzęciu negatywne znaczenia. Nic zatem dziwnego, że zostało ono powiazane $z$ wampirem - żywym trupem błąkającym się $\mathrm{w}$ nocy $\mathrm{w}$ poszukiwaniu krwi. W filmie nietoperz pojawia się kilkakrotnie. Po raz pierwszy widzimy jego lot w nieokreślonej pustej przestrzeni; można wysnuć tezę, iż zdarzenie to sytuuje się w obszarze mediacji, poza znanym porządkiem orbis interior-orbis exterior, gdzieś na granicy światów. Gdy Lucy budzi się z krzykiem, widzimy cień nietoperza odlatującego od okna. Słusznie uczynimy, stwierdzajac, iż zwierzę reprezentuje wampira, który zanim jeszcze przybył do Wiesmaru, nawiązał swego rodzaju kontakt $z$ żona Harkera. Po raz kolejny widzimy nietoperza już w sypialni Lucy - wspina się po firance i znika w zwojach zasłon. Może to oznaczać, że wampir przełamał już granicę - wlatując pod postacia nietoperza do pokoju kobiety, wkroczył w obręb ludzkiej ekumeny.

Druga forma zwierzęca, którą bardzo często przybiera wampir jest postać wilka. Według G. Duranda wilk jest zwierzęciem najbardziej przerażającym dla wyobraźni ludzi Zachodu ${ }^{26}$. Niektórzy uczeni wskazuja na fakt, iż wilk był bardzo często poczytywany za wysłannika świata chtonicznego. Postać wilka, a właściwie wilkołaka, ściśle łączy się $z$ idea wampira. W wielu ludowych podaniach i legendach następuje kontaminacja wątków związanych $z$ tymi dwiema postaciami ${ }^{27}$. Niejednokrotnie dochodziło do ich utożsamienia; niekiedy twierdzono również, iż wilkołak po śmierci stawał się wampirem. Wilk, co prawda, nie pojawia się w filmie Nosferatu wampir w całej swojej okazałości, jednak jego związek $z$ noca i wampirem zostaje odnotowany, kiedy Dracula prosi Harkera, aby ten wsłuchał się w nocne wycie wilków: „proszę posłuchać, to muzyka dzieci nocy".

\footnotetext{
25 Tamże.

26 M. Janion, dz. cyt., s. 156.

27 Tamże, s. 24.
} 
Oprócz wilka i nietoperza w filmie obecne sa odgłosy rozmaitych ptaków nocnych. Łatwo rozpoznać w nich pohukiwanie sowy czy kwilenie puszczyka. Ptaki te również sa powiąane $z$ postacią wampira, szczególnie puszczyk, którego starożytni Rzymianie nazywali strix (stąd polska strzyga). Był on określany jako ptak grobowy, wieszczacy swoim głosem śmierć i niepowodzenie ${ }^{28} . Z$ kolei w polskiej „demonologii” ludowej sowa była wiąana $z$ diabłem i stanowiła obiekt wielu przesądów i wierzeń ${ }^{29}$. Wierzono na przy$\mathrm{kład,} \mathrm{iż} \mathrm{w} \mathrm{ciagu} \mathrm{dnia} \mathrm{pozostaje} \mathrm{martwa,} \mathrm{a} \mathrm{ożywa} \mathrm{dopiero} \mathrm{noca.} \mathrm{Od-}$ głosy nocnych ptaków stanowia zatem swego rodzaju symboliczna ścieżke dźwiękową do filmu Nosferatu wampir, dopełniając sferę wizualną i narracyjna filmu.

Kończąc, chciałbym zrekapitulować rozważania dotyczące symboli zawartych w obrazie filmowym W. Herzoga. Tym, co wyraźnie zwraca uwagę, jest nieprzebrana wprost ilość motywów i sytuacji symbolicznych, które można interpretować na bardzo wiele sposobów. Zaproponowany ciąg symboli: zło (wampir) - śmierć - noc - księżyc - kobieta - krew - zwierzęta nocne (lunarne) miał za zadanie dopełnić, poprzez odniesienia do innych tekstów i kontekstów kultury, obrazy symboliczne przedstawione $\mathrm{w}$ dziele filmowym. Wydaje mi się, iż procedura amplifikacji zaproponowana przez Fredericksena sprawdziła się przy okazji interpretacji wątków symbolicznych obecnych w opisywanym filmie. Przypomnijmy: wedle słów amerykańskiego filmoznawcy: „amplifikacja nie rozwiązuje zawiłości symbolu, nie rozkłada go analitycznie. Dostarcza jedynie paralelnych wobec interpretowanego symbolu ekspresji zaczerpniętych $\mathrm{z}$ religii, mitologii, folkloru, takich jednak, które maja podobny temat, znaczenie i funkcję"30.

\section{Bibliografia}

Ariés P., Człowiek $i$ śmierć, Warszawa 1989.

Battistini M., Symbole i alegorie, Warszawa 2005.

Czaja D., Symbol i film. Uwagi metodologiczne, „Polska Sztuka Ludowa. Konteksty” 1992, nr 3-4.

Durand G., Wyobraźnia symboliczna, Warszawa 1986.

Eliade M., Traktat o historii religii, Warszawa 2000.

Janion M., Wampir. Biografia symboliczna, Gdańsk 2002.

28 Tamże, s. 20 .

${ }^{29}$ L. Stomma, Antropologia kultury wsi polskiej XIX i XX wieku oraz wybrane eseje, Łódź 2002, s. 187.

30 D. Czaja, dz. cyt., s. 41. 
Jung C. G., Typy psychologiczne, Warszawa 2009.

Kowalski P., Kultura magiczna. Omen, przesad, znaczenie, Warszawa 2007.

Petoia E., Wampiry i wilkołaki. Źródła, historia, legendy od antyku do współczesności, Warszawa 2010.

Ricoeur P., „Symbol daje do myślenia”, [w:] tenże, Egzystencja i hermeneutyka: rozprawy o metodzie, wyb. i oprac. S. Cichowicz, Warszawa 2003.

Ricoeur P., Symbolika zła, Warszawa 2002.

Roux J.-P., Krew. Mity, symbole, rzeczywistość, Kraków 1994.

Stomma L., Antropologia kultury wsi polskiej XIX i XX wieku oraz wybrane eseje, Łódź 2002.

\section{Filmografia}

Nosferatu - symfonia grozy, reż. W. Murnau, 1922.

Nosferatu wampir, reż. W. Herzog, 1979.

\section{Abstract}

This article is an attempt to interpret the film Nosferatu by Werner Herzog in terms of symbolic anthropology. Through the use of Jungian amplification procedures and the theory of symbols developed by phenomenology and hermeneutics author tries to explain the symbolic references contained in the film, and show how the symbols help to understand each other within a single text of culture.

Key words: anthropology, film, symbol, amplification, Nosferatu. 